\title{
D 101２２段階終端状態制御によるサーボプレスの衝撃制御
} Shock Control of a Servo Press Using Two-Staged Final-State Control ○学 福崎 淳一 (慶大院), 正 成川 輝真 (慶大院), 正 西村 秀和 (慶大院), 伊藤 博幸 (コマツ), 有壁 剛生（コマツ）

\author{
Junichi FUKUZAKI, Keio University, 4-1-1, Kohoku, Yokohama, Kanagawa 223-8526 \\ Terumasa NARUKAWA, Keio University, 4-1-1, Kohoku, Yokohama, Kanagawa 223-8526 \\ Hidekazu NISHIMURA, Keio University, 4-1-1, Kohoku, Yokohama, Kanagawa 223-8526 \\ Hiroyuki ITOU, KOMATSU, 1200, Manda, Hiratsuka, Kanagawa 254-8567 \\ Takeo ARIKABE, KOMATSU, 1200, Manda, Hiratsuka, Kanagawa 254-8567
}

Recently, servo presses have become widely used in manufacturing companies since they have the capability of high accuracy and free motion of the slide. This paper describes the optimum trajectory to achieve target values of the bottom dead point and the contact force between the slide and the die cushion (DC), and shows its implementation method. The optimum trajectory is derived using final-state control by dividing into two stages from the collision of the slide and DC until reaching the bottom dead point. Effectiveness from the viewpoint that controlled the DC load and the bottom dead point is shown by using two degrees of freedom control system as a method for following to the optimum trajectory.

Key Words: Servo Press, Final-State Control, Shock Control, Optimal Trajectory

\section{1. 絙宫}

近年, 自動車部品や電子部品の加工に使われるプレス機 械として, 駆動源にサーボモータを用いることで, 加工軌 道を自由に決定できるフリーモーションという優れた能 力を有するサーボプレスが注目を浴びている(1). サーボプ レスに関する先行研究 ${ }^{(2,3)}$ では, スライドのフリーモーショ ンを利用することで，これまでに実現できなかったような 高精度な加工事例が示され, 成形性能・生産性の向上が報 告されている. しかし，これらの研究で用いられている加 工時のスライド軌道は, 従来のプレス機械で使われていた 軌道を参考にして決定されたものであり, フリーモーショ ン機能の効果を最大限に発揮しているとは言えない。実際 にサーボプレスが使われている現場では, スライドの動き は職人の経験や勘によって決められており, スライド軌道 の決定方法およびその実現方法は必ずしも明確ではない(4). さらに, 最近ではハイテン材などの難加工材がプレス素 材として使われるようになり, 製品の加工精度の安定性が 求められている(5). また, 騒音・振動および消費エネルギ 一の低減などの付加価値への要求が増加している( ${ }^{(6)}$. こう した状況からここれまでの経験や勘だけでスライド軌道を 決定するのではなく, 適切な目標を設定した上でスライド 軌道を決定する方法を検討する必要がある(7).

本論文では, 成形性能の向上を念頭におき, 成形性能の 指標となるスライドの下死点とスライドとダイクッショ ン (以下, $\mathrm{DC}$ と略記) の接触荷重 (以下, $\mathrm{DC}$ 荷重之略記) を所望の時間内に目標値へ到達させるためのスライドの 目標軌道を導出する.スライドと DC を独立に制御するこ とが可能なサーボプレスを模擬して製作した実験装置の パラメータを定め, 力学モデルを導出する. 目標軌道の導 出には終端状態制御(8)を用いる。終端状態制御により得ら れた目標軌道を実現するために，PI 制御をフィードバッ ク制御系とした 2 自由度制御系を用いる. 最後に, 目標軌 道を正弦波としたときと応答を比較する.

\section{2. サーポブレスのカ学モデルと実䟻堆}

スライドと DC を独立に制御することが可能なサーボプ レスを模擬して製作した実験装置とその力学モデルを図 1 に示す。この実験装置は, クラウン, スライド, DC から
構成される. スライドと DC 制御用にリニアモータを使用 する. リニアガイドによりスライドと DC は上下方向にの み運動する。

サーボプレスのカ学モデルは, 上下方向の振動を模擬す るためにばねとダンパを付加する. $m_{c}$ はクラウン質量, $m_{s}$ はスライド質量, $m_{d}$ は DC 質量, $k_{c}$ はフレーム剛性， $c_{c}$ は フレームの粘性減衰係数, $k_{s}$ は接触剛性, $c_{s}$ は粘性係数で ある. $a_{i r}$ はエアシリンダによるカを表す. $u_{1}$ はスライド側 アクチュエータによるカ, $u_{2}$ は DC 側アクチュエータによ る力であり, $f_{s}$ はスライドへの力を, $f_{d}$ はDCへの力を表す. それぞれのパラメータの值を表 1 に示す。

クラウン, スライド, DC 各質点の運動方程式は次のよ うに与えられる。

$$
\begin{aligned}
& m_{c} \ddot{x}_{c}=-k_{c} x_{c}-c_{c} \dot{x}_{c}-u_{1}+m_{c} g \\
& m_{s} \ddot{x}_{s}=-k_{s}\left(x_{s}-x_{d}\right)-c_{s}\left(\dot{x}_{s}-\dot{x}_{d}\right)+u_{1}+m_{s} g \\
& m_{d} \ddot{x}_{d}=-k_{s}\left(x_{d}-x_{s}\right)-c_{s}\left(\dot{x}_{d}-\dot{x}_{s}\right)+m_{d} g-u_{2}-a_{i r}
\end{aligned}
$$

状態ベクトルを

$$
\mathbf{x}=\left[\begin{array}{llllll}
x_{c} & x_{s} & x_{d} & \dot{x}_{c} & \dot{x}_{s} & \dot{x}_{d}
\end{array}\right]^{T}, \mathbf{u}=\left[\begin{array}{ll}
u_{1} & u_{2}
\end{array}\right]^{T}
$$

とすると, 式(1),(2),(3)から, 状態方程式

$$
\dot{\mathbf{x}}=\mathbf{A x}+\mathbf{B u}+\mathbf{E}
$$

を得る.ここで, 各行列は以下のとおりである.

$$
\begin{aligned}
& \mathbf{A}=\left[\begin{array}{cccccc}
-\frac{k_{c}}{m_{c}} & 0 & 0 & -\frac{c_{c}}{m_{c}} & 0 & 0 \\
0 & -\frac{k_{s}}{m_{s}} & \frac{k_{s}}{m_{s}} & 0 & -\frac{c_{s}}{m_{s}} & \frac{c_{s}}{m_{s}} \\
0 & \frac{k_{s}}{m_{d}} & -\frac{k_{s}}{m_{d}} & 0 & \frac{c_{s}}{m_{d}} & -\frac{c_{s}}{m_{d}}
\end{array}\right] \\
& \mathbf{B}=\left[\begin{array}{cccc}
\mathbf{0}_{\mathbf{1} \times 3} & -\frac{1}{m_{c}} & \frac{1}{m_{s}} & 0 \\
\mathbf{0}_{\mathbf{1 \times 3}} & 0 & 0 & -\frac{1}{m_{d}}
\end{array}\right]^{T}, \mathbf{E}=\left[\begin{array}{llll}
\mathbf{0}_{\mathbf{1 \times 3}} & g & g & \mathrm{~g}-\frac{a_{i r}}{m_{d}}
\end{array}\right]^{T}
\end{aligned}
$$




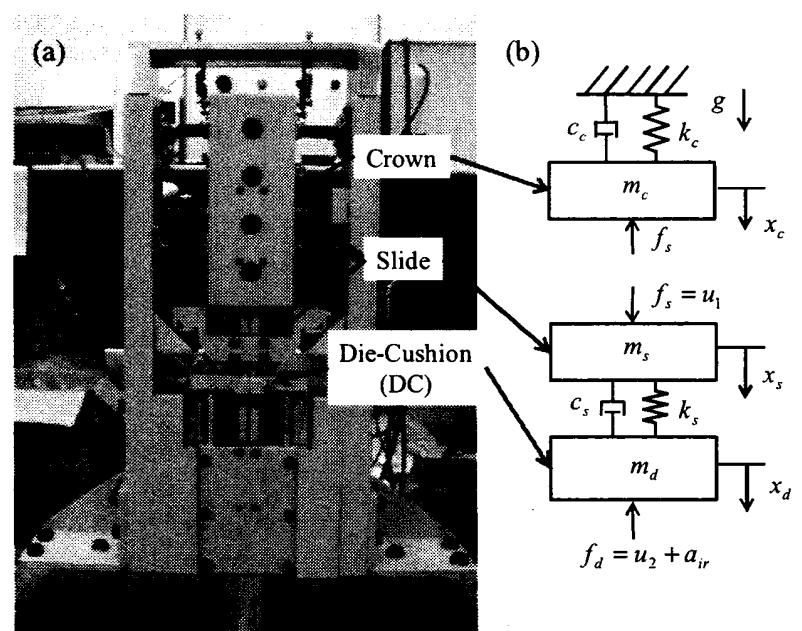

(a) Experimental setup

(b) Dynamical model

Fig.1 Experimental setup and dynamical model of servo press

\begin{tabular}{|c|c|}
\multicolumn{2}{|c|}{ Table 1 Parameter values } \\
\hline Parameter & Value \\
\hline Crown mass & $20 \mathrm{~kg}$ \\
Slide mass & $4.7 \mathrm{~kg}$ \\
DC mass & $2.8 \mathrm{~kg}$ \\
Air cylinder force & $100 \mathrm{~N}(0.5 \mathrm{MPa})$ \\
Stiffness of contact portion & $1 \times 10^{6} \mathrm{~N} / \mathrm{m}$ \\
Viscous damping coefficient of & $400 \mathrm{Ns} / \mathrm{m}$ \\
contact portion & $2 \times 10^{5} \mathrm{~N} / \mathrm{m}$ \\
Stiffness of Crown & $300 \mathrm{Ns} / \mathrm{m}$ \\
Viscous damping coefficient of crown & $\pm 120 \mathrm{~N}$ \\
Max. value Actuator force of slide & $\pm 50 \mathrm{~N}$ \\
Max. value Actuator force of DC &
\end{tabular}

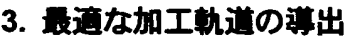

\section{1. 敦部指儤}

スライドが DC に衝突してから下死点に到達するまでの スライド軌道を加工軌道とする. 最適な加工軌道（以下, 最適軌道と略記）を導出する際の指標には，成形性能に大 きな影響を与えるスライドの下死点と DC 荷重を用いる. さらに, 生産性の向上を目的として, 下死点到達時間を指 標に加える. 成形性能と生産性を高めるために, 最適軌道 の設計指標を以下のように与える.

・ スライドとDCが衝突後に, DC 荷重は, オーバーシュ 一トが小さく，かつ，なるべく早く目標值 $100 \mathrm{~N}$ に到 達する

・ DC 荷重は, スライドが下死点 $10 \mathrm{~mm}$ に移動するまで 目標値 $100 \mathrm{~N}$ を保つ

・ スライドと DC が衝突後に, スライドは, 下死点 $10 \mathrm{~mm}$ をオーバーシュートすることなく, かつ, なるべく早 く下死点 $10 \mathrm{~mm}$ に到達する

・ スライドと DC のアクチュエータによる力は最大值を 超えない

これらの指標に基づき, 最適軌道の導出を行う.

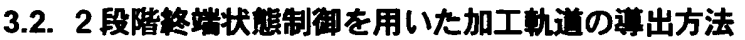

終端状態制御 ${ }^{(8)}$ は, 初期状態と目標とする状態およびそ れに到達するまでの時間を指定し，これを害現するための 最適な制御入力を導出する方法である.この方法は下死点 の精度が重要となるプレス加工に適していると考えられ る. 本論文では, 終端状態制御を用いて最適軌道を導出す る.
終端状態制御によって得られる入力 $\mathbf{u}$ の始点と終点の值 を任意に指定するために, 入力 $\mathbf{u}$ の一階微分 $\mathbf{u}$ を新たに制 御入力とした拡大系を構成する.

$$
\dot{\mathbf{x}}_{\mathrm{a}}=\mathbf{A}_{\mathrm{a}} \mathbf{x}_{\mathrm{a}}+\mathbf{B}_{\mathrm{a}} \dot{\mathbf{u}}+\mathbf{E}_{\mathrm{a}}
$$

拡大系の新たな状態べクトルは状態方程式(5)の状態べク トル $\mathbf{x}$ と入力 $\mathbf{u}$ から $\mathbf{x}_{\mathbf{a}}=\left[\mathbf{x}^{T} \mathbf{u}^{T}\right]^{T}$ として与えられる.ここで,

$$
A_{2}=\left[\begin{array}{cc}
A & B \\
0_{2 \times 6} & 0_{2 \times 2}
\end{array}\right], B_{2}=\left[\begin{array}{c}
0_{6 \times 2} \\
I_{2}
\end{array}\right], E_{2}=\left[\begin{array}{c}
E \\
0_{2 \times 1}
\end{array}\right]
$$

である. 式(6)を離散化すると, 以下の離散時間方程式を得 る.

$$
\begin{aligned}
& \dot{\mathbf{x}}_{\mathrm{d}}(k+1)=\mathbf{A}_{\mathrm{d}} \mathbf{x}_{\mathrm{d}}(k)+\mathbf{B}_{\mathrm{d}} \dot{\mathbf{u}}+\mathbf{E}_{\mathrm{d}} \\
& (k=0,1 \cdots, N-1)
\end{aligned}
$$

式(7)と出力行列 $\mathbf{C}$ により, 目標時間 $N \Delta t$ 後の部分状態量 である出力行列 $\mathbf{y}(N)$ は

$$
\begin{aligned}
& \mathbf{y}(N)=\mathbf{C x}_{\mathbf{d}}(N) \\
& =C A_{d}{ }^{N} x_{d}(0)+C \bar{A}_{d} \bar{E}_{d}+C \bar{B}_{d} \overline{\dot{u}} \\
& \overline{\mathbf{A}}_{\mathrm{d}}=\left[\mathbf{A}_{\mathrm{d}}{ }^{N-1}, \mathbf{A}_{\mathrm{d}}{ }^{N-2}, \cdots, \mathbf{A}_{\mathrm{d}}, \mathbf{I}\right] \\
& \overline{\mathbf{E}}_{\mathbf{d}}=\left[\mathbf{E}_{\mathbf{d}}{ }^{T}, \mathbf{E}_{\mathbf{d}}{ }^{T}, \cdots, \mathbf{E}_{\mathbf{d}}{ }^{T}\right]^{T} \\
& \overline{\mathbf{B}}_{\mathrm{d}}=\overline{\mathbf{A}}_{\mathrm{d}} \mathbf{B}_{\mathrm{d}}, \overline{\dot{\mathbf{u}}}=\left[\dot{\mathbf{u}}^{T}(0), \dot{\mathbf{u}}^{T}(1), \cdots, \dot{\mathbf{u}}^{T}(N-1)\right]^{T}
\end{aligned}
$$

である.ただし， $\overline{\mathbf{E}}_{\mathrm{d}}$ において， $\mathbf{E}_{\mathrm{d}}$ の数は $\mathrm{N}$ 個である. 式 (8)により, 出力 $\mathbf{y}(\mathbf{N})$ を目標出力 $\mathbf{y}_{\mathbf{f}}$ に到達させるためのフィ ードフォワード入力 $\overline{\dot{\mathbf{u}}}$ は

$$
\overline{\dot{\mathbf{u}}}=\overline{\mathbf{B}}_{\mathrm{d}}{ }^{T} \mathbf{C}^{T}\left(\mathbf{C} \overline{\mathbf{B}}_{\mathrm{d}} \overline{\mathbf{B}}_{\mathrm{d}}{ }^{T} \mathbf{C}^{T}\right)^{-1}\left(\mathbf{y}_{\mathrm{f}}-C A_{\mathrm{d}}{ }^{N} \mathbf{x}_{\mathrm{d}}(0)-\overline{C A}_{\mathrm{d}} \overline{\mathbf{E}}_{\mathrm{d}}\right)
$$

で与えられる。

本論文では，スライドと DC が衝突してからそれぞれの 時間で DC 荷重と下死点の二つの指標を満たすために, 衝 笑してから下死点に到達するまでを 2 段階に分けて終端 状態制御（以下，2段階終端状態制御之略記）を用いて最 適軌道を導出する. 2 段階終端状態制御を用いる際に, 1 段階目で, DC 荷重の制御をスライドと DC の変位のみで 行い, 2 段階目で下死点の制御を行う. このことから, 最 適軌道を導出する際の設計パラメータは，1段階目の終端 時間 $t_{1}, 1$ 段階目の終端時間のスライド変位 $\hat{x}_{s}, 2$ 段階目 の終端時間 $t_{2}$ とスライドの衝突初速度がある.これらのパ ラメータを適切に設定することで, 加工軌道の導出を行い, 最適軌道の設計指針を示す.

\section{3. 加工㢹道の萁出例}

単純な軌道である振幅 $10 \mathrm{~mm}$, 周期 $1 \mathrm{~s}$ の正弦波を参考 に, $t_{2}=0.25 \mathrm{~s}$ とし, $t_{1}=30 \mathrm{~ms}, \hat{x}_{s}=2 \mathrm{~mm}$ と設定して軌道 の導出を行う. 初期状態は静止している DC にスライドが 初速度 $0.06 \mathrm{~m} / \mathrm{s}$ で衝突する状態とし, この速度はスライド を振幅 $10 \mathrm{~mm}$, 周期 $1 \mathrm{~s}$ の正弦波で動作させたときの衝突 速度である. 1 段階目の終端状態で出力方程式 $\mathbf{C}_{\mathbf{1}}$ と目標出 力 $\mathbf{y}_{\mathbf{f l}}$ をそれぞれ

$$
\mathbf{C}_{1}=\left[\begin{array}{cccccccc}
0 & 1 & 0 & 0 & 0 & 0 & 0 & 0 \\
0 & 0 & 1 & 0 & 0 & 0 & 0 & 0 \\
0 & 0 & 0 & 0 & 1 & -1 & 0 & 0
\end{array}\right], \mathbf{y}_{\mathrm{n}}=\left[\begin{array}{c}
0.002 \\
0.002-\frac{100}{k_{s}} \\
0
\end{array}\right]
$$


とし，DC 荷重が目標荷重となるようにスライド変位，DC 変位を与える. 2 段階目の初期状態は 1 段階目の終端状態 を使用する. 2 段階目の終端状態で出力方程式 $\mathbf{C}_{2}$ と目標出 力 $\mathbf{y}_{\mathbf{n}}$ をそれぞれ

$$
\mathbf{C}_{2}=\left[\begin{array}{llllllll}
0 & 1 & 0 & 0 & 0 & 0 & 0 & 0 \\
0 & 0 & 1 & 0 & 0 & 0 & 0 & 0 \\
0 & 0 & 0 & 0 & 1 & 0 & 0 & 0 \\
0 & 0 & 0 & 0 & 0 & 1 & 0 & 0
\end{array}\right], \mathbf{y}_{\mathrm{n} 2}=\left[\begin{array}{c}
0.01 \\
0.01-\frac{100}{k_{s}} \\
0 \\
0
\end{array}\right]
$$

とし，下死点が $10 \mathrm{~mm} ， \mathrm{DC}$ 荷重が目標荷重となるように スライド変位, DC 変位を設定する.

図 2 に 2 段階終端状態制御を用いたときのスライド軌道, DC 荷重, スライド・DCへのアクチュエータの力を示す. 図 2(a)において，スライド変位は衝突後 $0.25 \mathrm{~s}$ でオーバー シュートせずに下死点 $10 \mathrm{~mm}$ に到達していることがわか る.図 2(b)から DC 荷重は衝突後 $30 \mathrm{~ms}$ で $100 \mathrm{~N}$ に到達し, その後ほぼ $100 \mathrm{~N}$ で一定である. 図 2(c)から, スライド, DC ヘのアクチュエータによる力は, 制約を満たしている ことがわかる.これらのことから，設計指標が満たされた 軌道が導出されていることが確認できる.

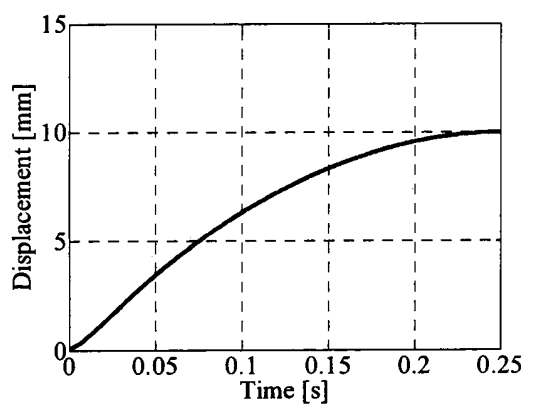

(a) Slide displacement

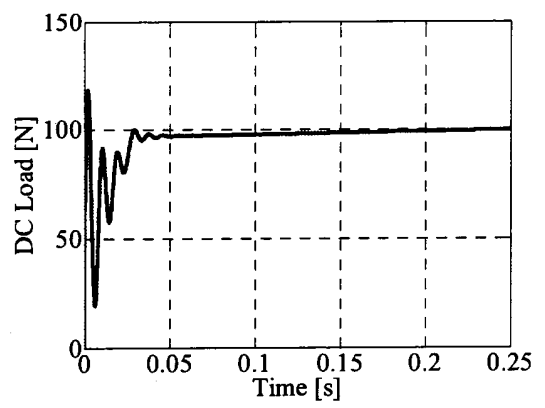

(b) DC load

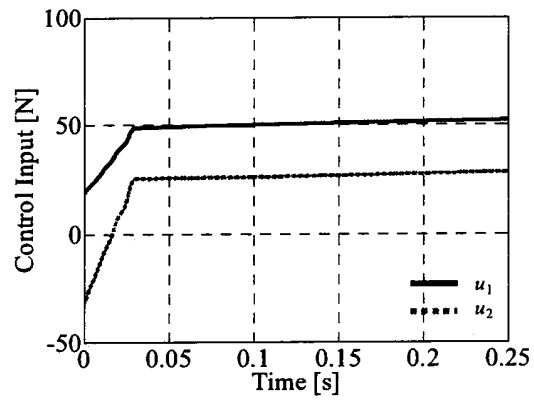

(c) Control input of slide and DC

Fig.2 Trajectory using the two-staged final-state control

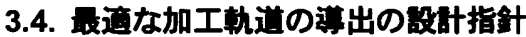

成形性能と生産性の向上を目指すために，設計パラメー 夕である $t_{1}, \hat{x}_{s}, t_{2}$ が軌道の導出に与える影響について検 討する。 具体的には， 3.3 で用いた設計パラメー夕の值を 基準として,$t_{1}$ と $\hat{x}_{s}$ を調整することで， $\mathrm{DC}$ 荷重を目標荷 重にオーバーシュートが少なく, かつ, 早く到達させ, $t_{2}$ を小さくすることによって，早く下死点に到達させること を検討した。

$t_{1}$ がスライド変位, DC 荷重, 及びスライドと DC のアク チュエー夕最大值に与える影響を図 3 に示す. 図 3(a), (d) から， $t_{1}$ を小さくすることで, スライド変位のオーバーシ ユートが増大することがわかる，また，図 3(b), (e)から衝 突直後の DC 荷重のオーバーシュートと目標 DC 荷重との 偏差は増減の雨方の場合があることがわかる. 図 3(c), (f) から, スライド側のアクチュエータの最大值は大きくなる が, $\mathrm{DC}$ 側は $t_{1}$ の範囲によって増隇が変わることがわかる.

次に， $\hat{x}_{s}$ が及ぼす影響を図 4 に示す. 図 4(a)から $\hat{x}_{s}$ を小さ くすることで，下死点のオーバーシュートを防ぐことがで きることがわかる．また，図 4(b)から DC 荷重の応答には ほとんど影響がないと言える. 図 4(c)から，スライド側の アクチュエータの最大值は小さくなるが, DC 側は大きく なることがわかる. 最後に, $t_{2}$ が与える影響を図 5 に示す.

図 5(a)から， $t_{2}$ を小さくした場合にスライドは下死点を才 一バーシュートせずに，下死点に到達しており，図 5(b)か ら DC 荷重はほぼ変化しないことがわかる. 図 5(c)におい て，スライドとDCのアクチュエータの最大值は大きくな ることがわかる.

以上の知見から設計パラメータが軌道設計に及ぼす影 響を表 2 に示す．表 2 から，最適軌道を導出するためのパ ラメー夕設定方法が次のように得られた。

1. $t_{1}$ を小さくし, 目標 DC 荷重への到達時間を早める.こ の時, スライド変位の下死点からのオーバーシュート が $10 \mathrm{~mm}$ を超える所で止める.

2. $\hat{x}_{s}$ をさくし， スライド変位が下死点をオーバーシュ 一トするのを防ぐ． $\hat{x}_{s}$ を小くする過程で下死点を超 えない軌道が得られた時の $\hat{x}_{s}$ を採用する.

3. スライド, $\mathrm{DC}$ のアクチュエータの出力が最大值を超え ない範囲で, 1. , 2.を繰り返し, 目標 DC 荷重への偏差 が一番小さい $t_{1}$ を決定する. その時間 $t_{1}$ において下死 点をオーバーシュートしない $\hat{x}_{s}$ を決定する.

4. $t_{1}$ と $\hat{x}_{s}$ を固定し, スライドと DC のアクチュエータの出 力が最大值を超えない範囲で, $t_{2}$ を小さくする.

図 6 に設計指針に基づき，パラメー夕設定方法を用いて, 最適軌道を導出した結果を示す. 図 6 から目標 DC 荷重到 達時間を $8 \mathrm{~ms}$, 下死点到達時間を $0.11 \mathrm{~s}$ まで短くすること ができ, 設計指標を満たす最適軌道が導出されたことがわ かる.

Table 2 Influence of design parameters

\begin{tabular}{|c|c|c|c|}
\hline & $t_{1}$ & $\hat{x}_{s}$ & $t_{2}$ \\
\hline & decrease & decrease & decrease \\
\hline $\begin{array}{c}\text { Overshoot of the DC } \\
\text { load }\end{array}$ & $\begin{array}{l}\text { decrease or } \\
\text { increase }\end{array}$ & NA & NA \\
\hline $\begin{array}{l}\text { Difference with the } \\
\text { targeted DC load }\end{array}$ & $\begin{array}{l}\text { decrease or } \\
\text { increase }\end{array}$ & NA & NA \\
\hline $\begin{array}{l}\text { Overshoot of } \\
\text { the slide displacement }\end{array}$ & increase & NA & NA \\
\hline Max. value of $u_{1}$ & increase & decrease & increase \\
\hline Max. value of $u_{2}$ & $\begin{array}{c}\text { decrease or } \\
\text { increase }\end{array}$ & increase & increase \\
\hline
\end{tabular}




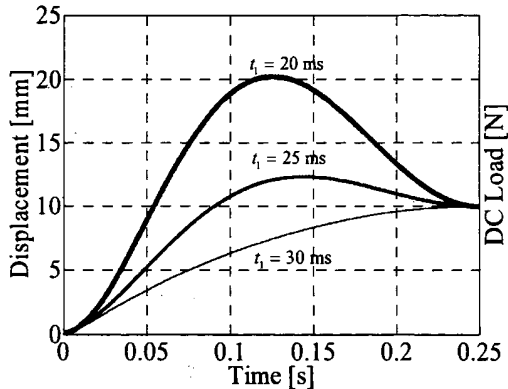

(a) Slide displacement

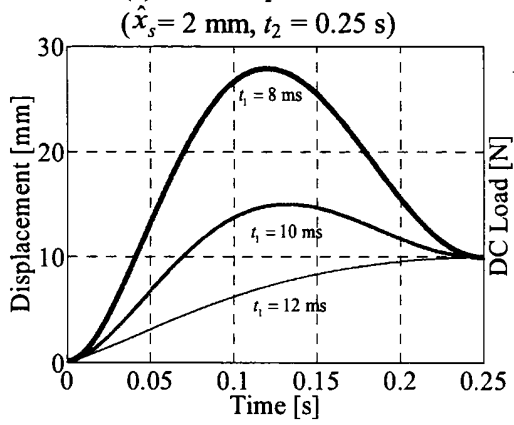

(d) Slide displacement

$\left(\hat{x}_{s}=0.65 \mathrm{~mm}, t_{2}=0.25 \mathrm{~s}\right)$

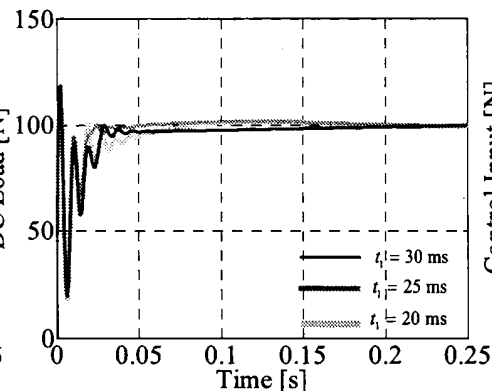

(b) DC load

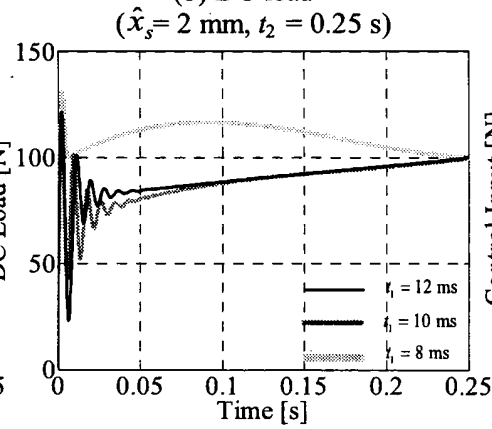

(e) DC load

$\left(\hat{x}_{s}=0.65 \mathrm{~mm}, t_{2}=0.25 \mathrm{~s}\right)$

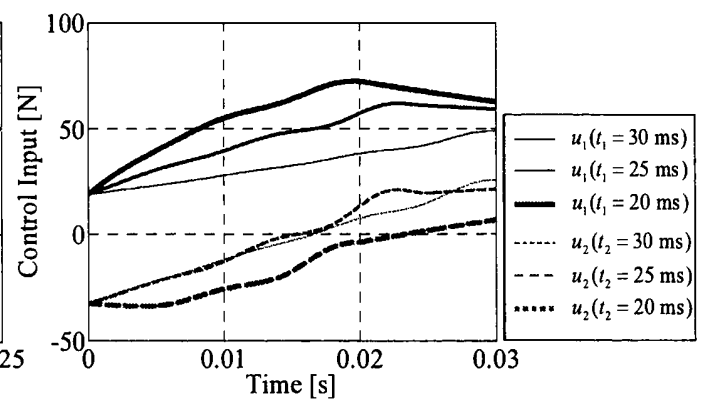

(c) Control Input of slide and DC $\left(\hat{x}_{s}=2 \mathrm{~mm}, t_{2}=0.25 \mathrm{~s}\right)$

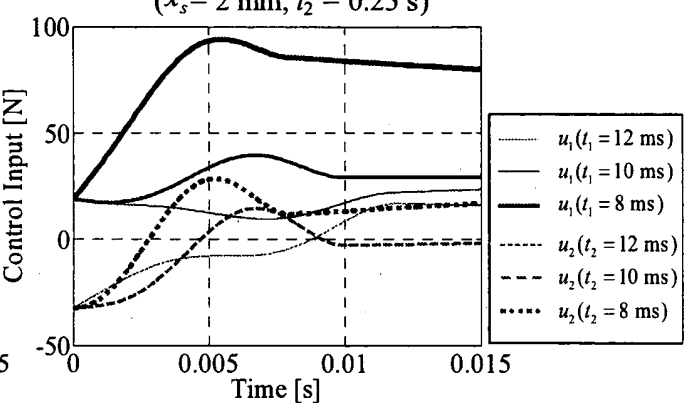

(f) Control Input of slide and DC $\left(\hat{x}_{s}=0.65 \mathrm{~mm}, t_{2}=0.25 \mathrm{~s}\right)$

Fig. 3 Trajectory using the two-staged final-state control when the final time in the first stage is adjusted.

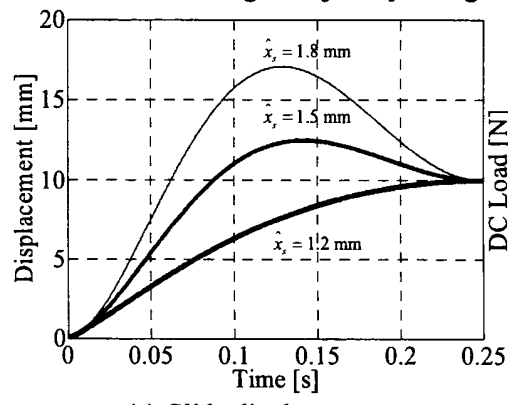

(a) Slide displacement

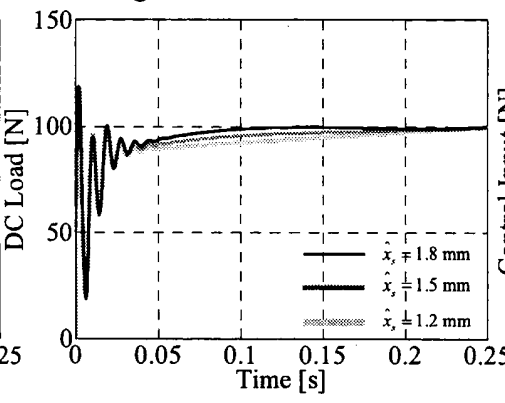

(b) DC load

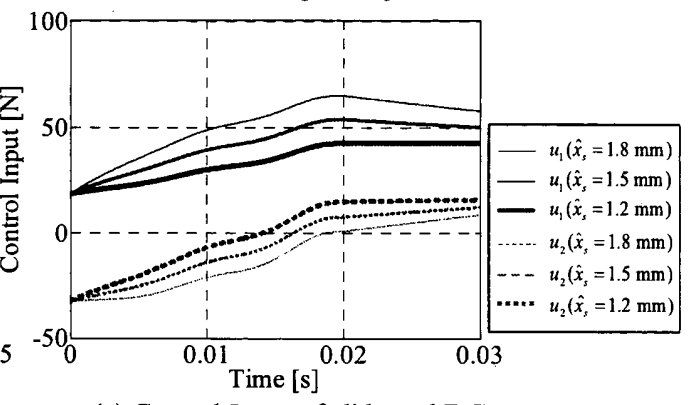

(c) Control Input of slide and DC

Fig.4 Trajectory using the two-staged final-state control when the final slide displacement in the first stage is adjusted. $\left(t_{1}=20 \mathrm{~ms}, t_{2}=0.25 \mathrm{~s}\right)$

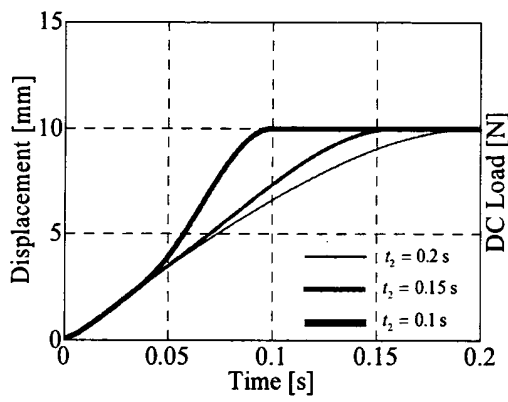

(a) Slide displacement

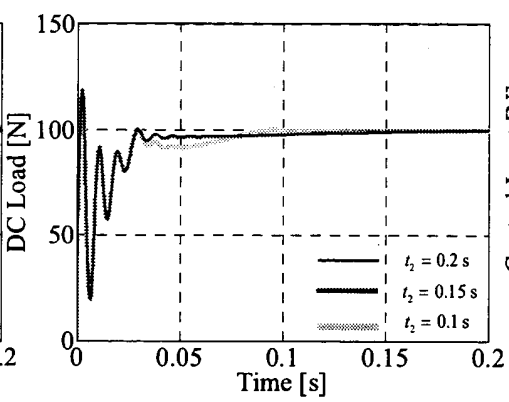

(b) DC load

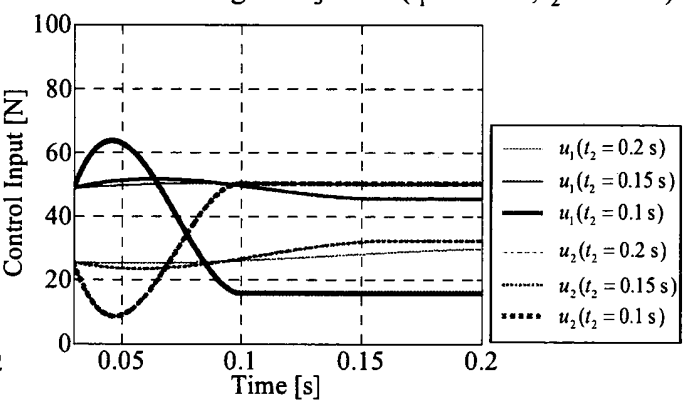

(c) Control Input of slide and DC

Fig.5 Trajectory using the two-staged final-state control when the final time in the second stage is adjusted. $\left(t_{1}=30 \mathrm{~ms}, \hat{x}_{s}=2 \mathrm{~mm}\right)$

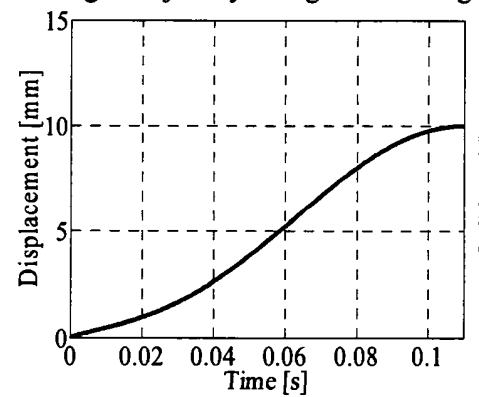

(a) Slide displacement

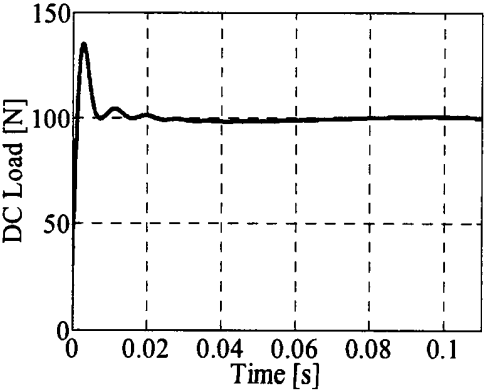

(b) DC load

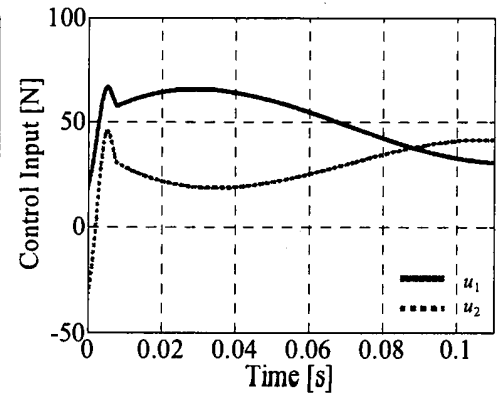

(c) Control Input of slide and DC

Fig.6Optimal trajectory using the two-staged final-state control $\left(t_{1}=8 \mathrm{~ms}, \hat{x}_{s}=0.38 \mathrm{~mm}, t_{2}=0.11 \mathrm{~s}\right)$ 


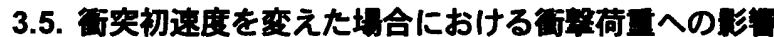
衝突初速度が DC 荷重に与える影響について検討する. 衝突初速度は $0.06 \mathrm{~m} / \mathrm{s}$ から $0.03 \mathrm{~m} / \mathrm{s}$ に変更し, 3.4 で示した パラメー夕設定方法を用いて最適軌道の導出を行う. 図 7 に最適軌道の導出結果を示す. 最適軌道の設計パラメータ はそれぞれ $t_{1}=8 \mathrm{~ms}, \hat{x}_{s}=0.25 \mathrm{~mm}, t_{2}=0.11 \mathrm{~s}$ とした. 図 7(a)からスライドはオーバーシュートせずに下死点に到達 しており，図 7(b)から衝突直後の DC 荷重の值が抑えられ ており，その後の振動も小さいことがわかる．これらのこ とから, 衝突初速度を変えた場合においても, 軌道の設計 指標に基づき, パラメー夕設定方法を用いることで, 最適 軌道が導出されていることを確認できる. また, 衝突直後 の DC 荷重の最大值は, 衝突初速度が $0.06 \mathrm{~m} / \mathrm{s}$ の場合と比 較して $20 \%$ 低減できている.

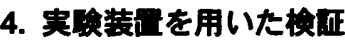

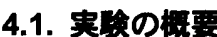

実験装置ではクラウン変位 $x_{c}$ をレーザー変位計で検出し， クラウンに対するスライド変位 $x_{s}-x_{c}$ と DC 変位 $x_{d}$ をリニア エンコーダで検出する. 状態量のスライド絶対変位 $x_{s}$ はク ラウン変位に対するスライド変位とクラウン変位から求 める. 速度信号は変位を近似微分して求める. DC 荷重は ロードセルを用いて測定する．スライドに衝突時の初速度 $0.06 \mathrm{~m} / \mathrm{s}$ を与えるために，スライドが DCに衝突するまで はスライドを振幅 $10 \mathrm{~mm}$, 周期 $1 \mathrm{~s}$ の正弦波に追従させる.

摩擦やパラメー夕誤差に対するロバスト性を確保する ために, フィードバック制御を加えた 2 自由度制御系を設 計する. 目標軌道は図 5 で示した軌道を採用し，フィード バック制御系には PD 制御を適用する.フィードバック制 御はスライドのみへの入力とし, スライドを下死点に到達 させるための制御を行う. 衝突直後は速度変化が大きいこ とから，1段階目はフィードバック制御は行わず, フィー ドフォワード入力のみで制御した．下死点到達後は，下死 点保持を行うために，スライドと DC の制御入力に下死点 到達時の釣り合いの力を補償として加えた.

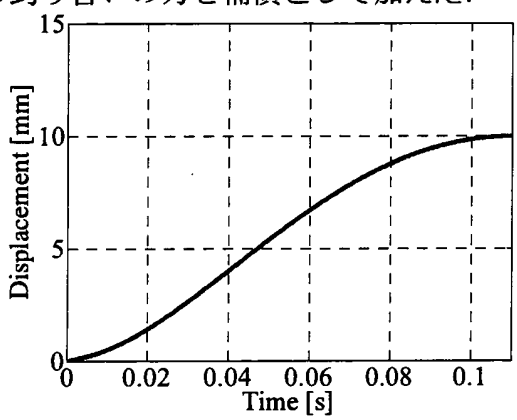

(a) Slide displacement

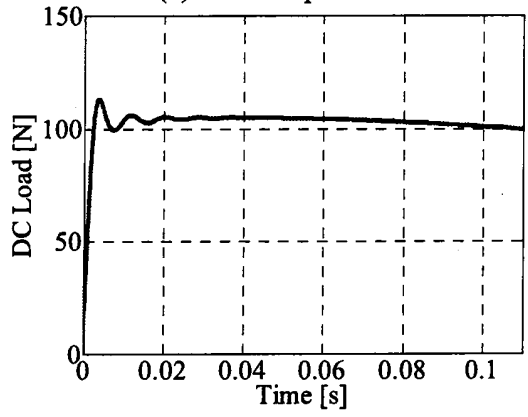

(b) DC load

Fig.7 Optimal trajectory using the two-staged final-state control when collision speed is changed

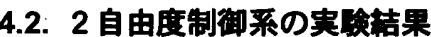

図 8 に 2 自由度制御系の実験結果を示すそこし，2 自 由度制御系全体のブロック線図を図 9 に示す. $k_{P}=7 \times 10^{4}$, $k_{I}=1.5 \times 10^{3}, k_{D}=6 \times 10^{2}$ とした．また，目標軌道を正弦波 に設定して, 目標軌道に対して PID 制御を施し，応答を比 較した. 正弦波は最適軌道と下死点到達時間が同じ振幅 10 $\mathrm{mm}$, 周期 $0.44 \mathrm{~s}$ と設定し, 目標軌道に対しては, スライド に関してのみ PID 制御を施し，DC 側に関しては一定值を 保持する方法で制御を行った. スライドへは PID 制御に加 え, エアシリンダ圧力補償 $(100 \mathrm{~N})$, スライド自重の補償を 行った. DCへの入力は一定值とし, DC 自重の補償を行っ た. 図 10 にそのブロック線図を示す. $k_{P}=7 \times 10^{4}, k_{I}=1.5$ $\times 10^{3}, k_{D}=6 \times 10^{2}$ とした. 正弦波への PID 制御の実験結果 を図 11 に示す. 図 8(a) と図 11(a)からそれぞれの制御方法 における目標軌道への追従性を比較すると，どちらも目標 軌道に追従し下死点に到達していることから，双方の制御 方法で追従性には差がないと言える，一方で，図 8(b) と図 11(b)の DC 荷重を比較すると，PID 制御と比べ， 2 自由度 制御系は衝突直後の DC 荷重のオーバーシュートを㧕えら れていることがわかる. また, 図 11(c)の PID 制御では, 衝 突直後はスライド側に大きな入力が発生しているのに対 して, 図 8(c)の 2 自由度制御系では, 衝突直後の入力が抑 えられていることがわかる.

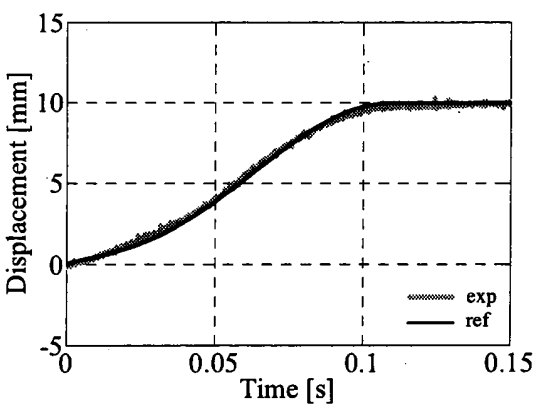

(a) Slide displacement

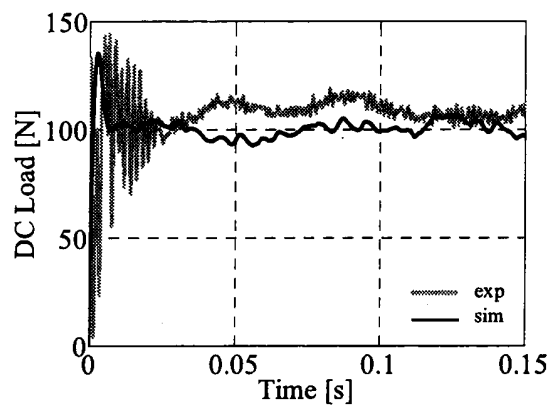

(b) DC load

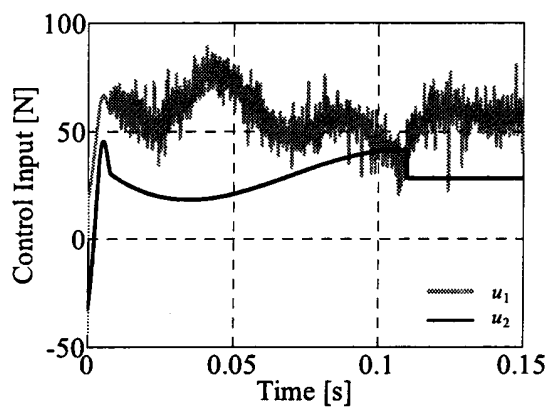

(c) Control input of slide and DC

Fig.8 Experimental results of two degrees of freedom control system 


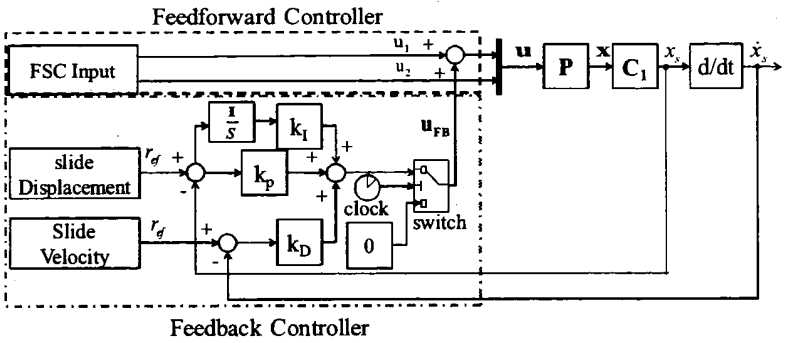

Fig.9 Block diagram of two degrees of freedom control system

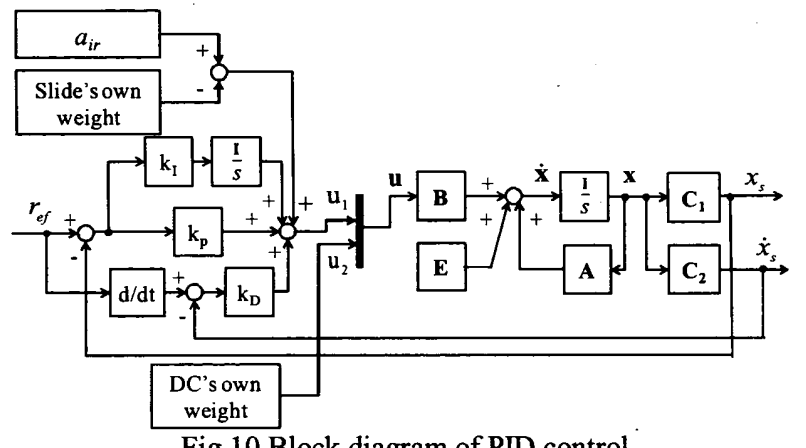

Fig.10 Block diagram of PID control

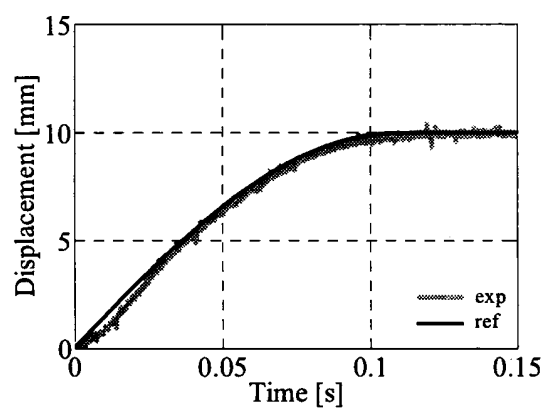

(a) Slide displacement

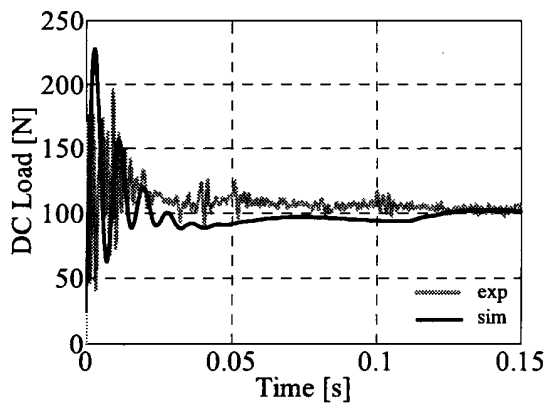

(b) DC load

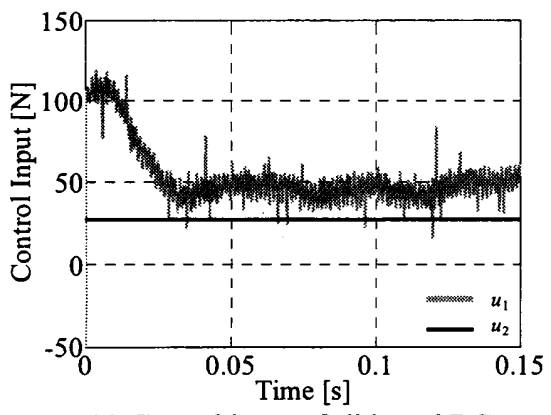

(c) Control input of slide and DC

Fig.11 Experimental results of PID control

\section{5. 結砉}

2 段階終端状態制御を用いて，スライドの最適軌道の導 出方法を示した. 設計指標として, DC 荷重, 下死点と下 死点到達時間を設定し，スライドと DC の衝突からスライ ドが下死点に到達するまでを 2 段階に分け，1 段階目で DC 荷重を制御し， 2 段階目で下死点を制御することで最 適軌道を導出した. 設計指標に基づき最適軌道を導出する 際に, 設計パラメータが, スライド変位, DC 荷重, 及び スライドとDC のアクチュエータ最大值に及ぼす影響を明 らかにすることで，パラメー夕設定方法を示した．1段階 目の時間とその終端におけるスライド変位を調整するこ とで, 目標 DC 荷重への偏差を小さくし, かつ下死点への オーバーシュートを防ぐことができ，2段階目の時間を調 整することで, 下死点到達時間を短縮することができるこ とを示した. また, 衝突初速度を変えた場合においても, パラメー夕設定方法を用いることで, 最適軌道を導出でき ることを示し，その時の DC 荷重への影響を比較した.

最適軌道に追従させる手法として，2 自由度制御系を用 いて実験を行い, DC 荷重と下死点の制御を行う観点から の有効性を示した.ここでは, 最適軌道から得られた入力 をフィードフォワード入力とし，フィードバック制御には PID 制御を用いた. また, 目標軌道を正弦波に設定し， ス ライドのみに PID 制御を施し, スライドを正弦波に追従さ せる制御実験を行い，応答を比較した． 2 自由度制御系を 用いると, スライドと DC 衝突直後の入力と衝撃を抑制で きることを示した.

\section{考文献}

（1）林央，サーボプレス，塑性と加工, 50, pp.92-93, 2009.

(2) 古閑伸裕, 久保雅亮, NC サーボブレスを利用したかえ り無しせん断, 塑性と加工, 48, pp.645-649, 2007.

(3) 鈴木裕一, 白神二栄, ハイブリッド AC サーボプレス のモーション制御, 日本機械学会 Dynamics and Design Conference, No.04-5, 2004.

(4) 畑幸男, 松本順次, KOMATSU TECHNICAL REPORT, 53, pp.44-51, 2007.

（5）江河隆幸，なぜ高強度䤡鈑が多用されるのか, 塑性と 加工, 46, pp.556-559, 2005.

(6) 佐藤章仁, 高強度鋼鈑の問題点とその対応, 塑性と加 工, 46, pp.548-551, 2005.

(7) 黒潟和彦, ハイブリッド AC サーボプレスシリーズ, プ レス技術誌, 41, pp.54-57, 2003.

(8) T. Totani, H. Nishimura, "Final-State Control Using Compensation Input", Trans. of the Society of Instrument and Control Engineers, 30, pp.253-260, 1994. 